\title{
Maize Residue as a Viable Substrate for Farm Scale Cultivation of Oyster Mushroom (Pleurotus ostreatus)
}

\author{
Abena O. Adjapong, Kwame D. Ansah, Faustina Angfaarabung, and Henry O. Sintim \\ Department of General Agriculture, School of Applied Science \& Technology, Sunyani Polytechnic, Sunyani, Ghana \\ Correspondence should be addressed to Henry O. Sintim; hosintim@gmail.com
}

Received 11 October 2015; Accepted 20 December 2015

Academic Editor: Albino Maggio

Copyright ( 2015 Abena O. Adjapong et al. This is an open access article distributed under the Creative Commons Attribution License, which permits unrestricted use, distribution, and reproduction in any medium, provided the original work is properly cited.

\begin{abstract}
In the search for alternatives to sawdust as growing media in commercial mushroom cultivation, three organic substrates obtainable as crop residue, maize husk, maize cob, and maize stalk, with each being supplemented with rice bran, were evaluated as growth media for the oyster mushroom, Pleurotus ostreatus (Kummer). For the tested alternatives to sawdust, the harvested weight of fruiting bodies that sprouted on a kilogram maize husk media per crop $(32.99 \mathrm{~g})$ was the highest. Sawdust media supported significantly $(P<0.001)$ heavier fruiting bodies $(42.18)$ than the maize residues. The peak mushroom harvests for the various substrates were obtained between the first and seventh fruiting body flushes. The biological efficiency of the substrates, which measured usable nutrients indicated that maize stalk supplemented with rice bran, was $39 \%$ compared to that of the sawdust media (60\%). The maize husk media and the maize cob media had biological efficiencies of $32 \%$ and $9.5 \%$, respectively. These results indicate that two of the tested growing media (maize stalk or husk) produced mushrooms with yield characteristics that were comparable to the well-used sawdust in the cultivation of oyster mushrooms. The environmental and economic parameters involved in the use and carting of sawdust make these on-farm crop residues a viable alternative for mushroom cultivation in especially nonforest zones of Ghana.
\end{abstract}

\section{Introduction}

Edible mushrooms include fungi that thrive on damp decaying organic matter alone or in combination with soil [1] as it depends on nutrients obtained from dead and decaying materials. Mushrooms have been used for food and medicine and have often been considered a luxurious food reserved for the elite [2]. Global mushroom production has increased tremendously, from about 0.3 million tons in 1961 to about 3.41 million tons in $2010[3,4]$. China is the leading producer of mushrooms worldwide, producing about $65 \%$ of global mushrooms and $85 \%$ of oyster mushroom worldwide [3]. Africa produces only $1 \%$ of the total world output of oyster mushroom [5].

Oyster mushroom (Pleurotus ostreatus, Kummer) is the second largest commercially produced and important edible mushroom in the world market [6] after Agaricus mushrooms. It is the most popular mushroom cultivated in Ghana and it also does well in other tropical and subtropical regions [7]. P. ostreatus has a unique adaptation to a wide range of lignocellulosic substrates $[2,8]$; hence, it is not uncommon to find wild oyster mushrooms sprouting naturally in clusters on dead trees. It is also an easy and a cost effective mushroom to grow [8]. Oyster mushroom is consumed for its taste and medicinal and nutritional properties [8]. It contains proteins, vitamins, and crude fibre and has been recommended for its lovastatin properties [6] to patients with cholesterol related ailments $[4,7,9]$. It is believed that oyster mushroom can prevent high blood pressure, constipation, and hangovers and can assist in the recovery from fatigue and again it is used as a soil conditioner in agriculture [2].

Oyster mushrooms have been cultivated using tree logs or containers such as shelves, boxes, bags, and bottles containing growing media [2]. Various crop residues have been used in producing oyster mushrooms either as main substrates or in combination with supplements [10]. Oyster mushroom can be grown on various substrates including paddy straw, maize stalks/cobs, vegetable plant residues, bagasse [11, 12], sawdust, wheat straw, cotton waste, waste paper, and cotton stalks $[13,14]$. The preferred method of cultivation is dependent on 
the mushroom variety, market demand, farmer's preferences, and availability of growing media [15].

In Ghana, oyster mushroom is cultivated using plastic bags filled with decomposed sawdust [16]. However, as wood (timber) becomes scarce, the unavailability of appropriate sawdust substrate becomes a limiting factor for mushroom cultivation in Ghana. In addition, the timber industry which provides the sawdust as a by-product from the timber mills is restricted to the forest zones. Mushroom growers outside the forest zones are therefore challenged with the carting cost of the sawdust which increases production cost. The development of cultivation techniques that utilizes other sustainable sources of substrates for oyster mushroom cultivation can fill the sawdust void and is likely to be adopted by mushroom growers.

The utilization of maize residues as substrate for oyster mushroom under controlled conditions has been reported by Atikpo et al. [15], Obodai et al. [16], and Onyango et al. [5]. Maize is one of the major crops grown in Ghana and its residues (husks, cobs, and stalks) are abundant and available during the year and could be exploited as a sustainable substrate for mushroom growing. The extrapolation of laboratory growing successes $[5,15,16]$ of mushroom on maize residues need to be tested under field conditions using homegrown crop varieties before it can be recommended to local farmers. This study investigated the relative performance of indigenous maize residues (cobs, husks, and stalks) in oyster mushroom cultivation under farmer field conditions. The potential of these substrates and with other supplements to support oyster mushroom cultivation was also determined.

\section{Materials and Methods}

2.1. Source of Substrates and Spawn. The study was conducted at BenCom farm at Techiman in the Brong Ahafo Region of Ghana, between March and July 2011. BenCom farm located at $7.5772^{\circ} \mathrm{N}, 1.9292^{\circ} \mathrm{W}$ is the largest mushroom farm in Ghana that produces about 2500 tons of mushrooms annually. Pleurotus ostreatus spawn was obtained from BenCom farms. Sawdust of unknown timber species was collected from a local sawmill at the Techiman timber market. The maize residues (husk, cob, and stalk) were abundantly available from local farmers.

2.2. Preparation of Growing Substrates. Ten (10) kg of sawdust was mixed with $0.5 \%$ lime to maintain $\mathrm{pH}$. The mixture was moistened to attain a moisture content of $70 \%$. The mixture was then heaped into a pyramidal shape and remixed at 4-day intervals to ensure good aeration. The mixture was adequately fermented and ready for bagging after 28 days. The maize husks and stalks were cut into approximately $4 \mathrm{~cm}$ lengths and the cobs were crushed to approximately $0.5-4 \mathrm{~cm}$. Each of the residues was then soaked in excess water for 12 hours. The excess water was drained out and the wet residue was sundried for one hour to obtain the maize residue substrate. In treatments with supplements, $840 \mathrm{~g}$ rice bran was admixed. Each substrate was bagged into one-kilogram lots using $33 \times$ $18 \mathrm{~cm}$ heat resistant propylene bags. Polyvinyl chloride (PVC) pipes were used to stiffen the spouts of the bags and these were sterilized at $100^{\circ} \mathrm{C}$ for 4 hours in a metal drum over naked flame and were allowed to cool before use.

2.3. Spawning, Incubation, and Fruiting. The bagged substrates were placed in a sterilized room and $50 \mathrm{~g}$ of mushroom spawn was inoculated into each $1 \mathrm{~kg}$ bag making a 5\% spawn. The thorough spawning technique was used to enhance mycelia growth where the spawn was completely mixed with the substrate. The bags were covered with a sterilized cotton wool and then paper, which was fastened in place with a rubber band. This was incubated at $26-28^{\circ} \mathrm{C}$ for about $20-34$ days in a well-ventilated room. Each treatment was replicated five times. The bags were moved to the growing house for fruiting when mycelia had fully grown. The PVC rings, cotton plugs, and the papers were removed to enhance aeration and stimulate pinning when the walls of the bags had been fully colonized. Holes were also created on the bags for emergence of fruiting bodies. Temperature and humidity were regulated by wetting the concrete floor and spawning bags.

2.4. Data Collection and Analyses. The fruiting bodies were pulled out and the number of mushroom and its fresh weight were recorded every six days for 6 consecutive weeks. The minimum period (6.33 days) between flushes reported by Bhatti et al. [17] was adopted. The total number of fruiting bodies, total number of flushes, and yield of each bag and total yield ( $g$ ) of the mushrooms were calculated after the cropping period. After the last harvest the dry weight of the spent substrate was determined by exposing it to direct sunlight until there was no further change in weight for 3 consecutive days. The biological efficiency (BE) of each treatment was calculated using the formula:

$$
\mathrm{BE}=\frac{\text { Total fresh weight of mushroom }(\mathrm{g}) \text { per substrate } \times 100}{\text { Dry weight of spent substrate }(\mathrm{g})} .
$$

The mushroom weight and numbers were square-roottransformed before statistical analyses. The data was subjected to analysis of variance (ANOVA) using GenStat 9th edition. Mean separation was done using Least Significant Difference and effects were declared significant at 5\% level.

\section{Results}

The number of fruiting bodies of oyster mushroom was significantly influenced by the different substrates. The four substrates sawdust, maize husk, maize stalk, and maize cobs significantly influenced the number of fruiting bodies of mushroom (Figure 1). Maize stalk substrate recorded the highest mean number of fruiting bodies per crop (5.17) and maize husks had the lowest 3.38 which was significantly different from the other substrates (Figure 3). Each of the substrates during the 7 -week harvesting period had different periods for peak mushroom fruiting body numbers. Sawdust, the traditional substrate for mushroom production in the locality, and maize husk produced the highest fruiting body flushes at the first flush harvesting week (Figure 1), while maize cobs and maize stalk had their highest peaks during the 


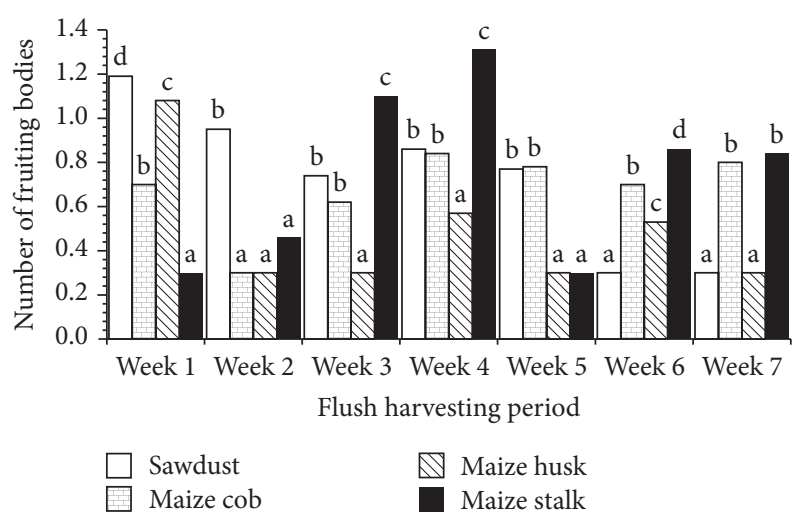

FIGURE 1: The effect of substrate material on fruiting body sprouts (flushes) over time. (1) Bars with the same Arabic numerals during a harvesting period are not significantly different $P<0.001$. (2) $50 \mathrm{~g}$ of mushroom spawn was mixed with $1 \mathrm{~kg}$ substrate and incubated at $26-28^{\circ} \mathrm{C}$ for about $20-34$ days. (3) The mushroom flushes were recorded over six weeks.

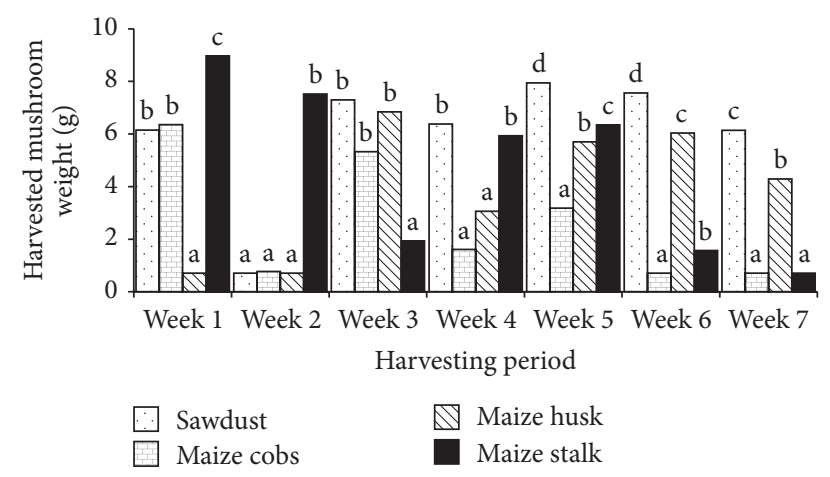

FIgURE 2: The effect of substrate material on mushroom yield over time. (1) Bars with the same Arabic numerals during a harvesting period are not significantly different $P<0.001$. (2) $50 \mathrm{~g}$ of mushroom spawn was mixed with $1 \mathrm{~kg}$ substrate and incubated at $26-28^{\circ} \mathrm{C}$ for about $20-34$ days. (3) The mushroom yield was recorded over six weeks.

fourth week. Supplemented substrates significantly affected the number of fruiting bodies that sprouted per crop. The average number of fruiting bodies obtained in each substrate alone was lower than when it was supplemented with rice bran. Among the substrates which were supplemented with rice bran, maize husks produced the highest mean number of fruiting bodies (2.15) per harvesting period followed by maize stalk (2.06) and the least was maize cobs which produced 1.28 fruiting bodies.

The substrates significantly influenced the fresh weight of mushroom produced (Figure 4). Sawdust recorded a significantly $(P<0.001)$ higher $(42.18 \mathrm{~g})$ fresh mushrooms per kilogram substrate in a crop and was followed by maize stalk (32.99 g), maize husk (27.55 g), and a significantly low mushroom weight from maize cob substrate $(18.67 \mathrm{~g})$. The fifth harvesting period gave the highest fresh mushroom weight and the least was during the second harvesting period (Figure 2). The highest harvested fresh mushroom weight

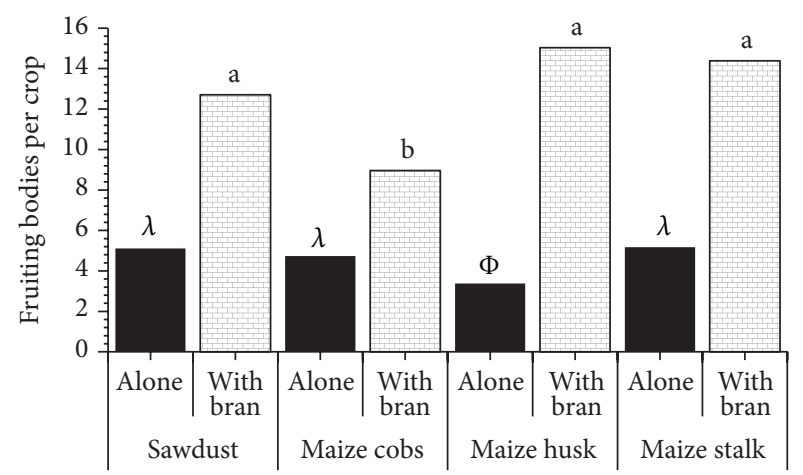

Figure 3: The effect of substrates on the total number of sprouted fruiting bodies in a crop. (1) Bars with the same Arabic letter for substrate material alone or same Greek letter for bran fortified substrates are not significantly different $P<0.001$. (2) Substrates with bran contain $8.4 \%$ rice bran.

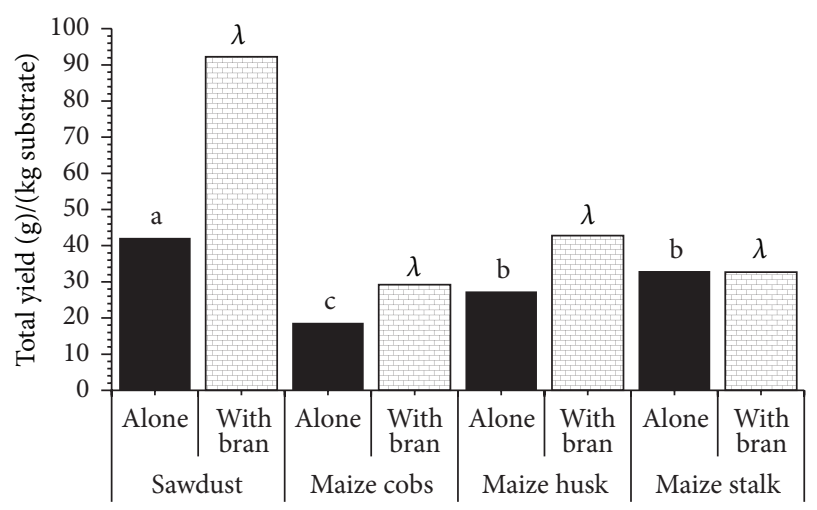

Figure 4: The effect of substrates on the yield of oyster mushrooms in a crop. (1) Bars with the same Arabic letter for substrate material alone or same Greek letter for bran fortified substrates are not significantly different $P<0.001$. (2) Substrates with bran contain $8.4 \%$ rice bran.

from a substrate was recorded on maize stalk during the first harvesting week (Figure 2). In the rice bran supplemented substrates, sawdust media resulted in the highest (92.2 g) fresh mushroom weight per kilogram substrate (Figure 4 ) but were not significantly different from either the maize cob (29.2 g), maize husk (42.8), or maize stalk (32.7 g).

The biological efficiency (BE) which is a function of the extent of substrate nutrient utilization was significantly different among the substrates. Sawdust had the highest biological efficiency of $60.1 \%$ and maize cobs had the lowest value of $14 \%$. Of the supplemented substrates, maize stalk gave the highest biological efficiency of $39.2 \%$ followed by maize husk. Maize cobs recorded the lowest biological efficiency of $9.5 \%$ (Figure 5).

\section{Discussion}

Several edible mushrooms have been successfully cultivated at commercial level worldwide using lignocellulose wastes as substrates [18]. An ideal substrate should contain nitrogen 


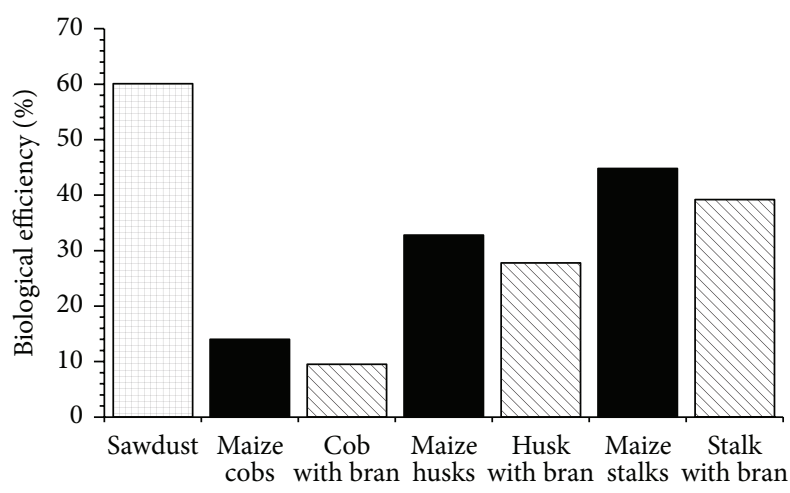

FIgURE 5: Biological efficiency (BE) of sawdust and maize residues. (1) Biological efficiency (BE) was a function of substrate usage to amount converted into harvested mushroom. (2) Substrates with bran contain $8.4 \%$ rice bran.

(supplement) and carbohydrates for rapid mushroom growth [19]. Various crop residues have been reported to have been used in producing oyster mushrooms either as main substrates or in combinations with supplements [10]. Oyster mushroom can be grown on various substrates including paddy straw, maize stalks/cobs, vegetable plant residues, bagasse [12], wheat straw [13], cotton waste, waste paper, and cotton stalks that are all suitable for high production capacity for oyster mushroom [14].

The response of the different substrates used shows differences in respect of time taken for formation of pinheads, maturation of fruiting bodies, period between flushes, number of flushes, and yield. Lozano [20] reported that seven harvestings were carried during 60 days, whereas Jiskani [21] reported 7.5 days between flushes and Bughio [22] recorded 9-15 days between flushes. There were 7 flushes within 42 days for all the substrates tested in this experiment based on our selected $5 \%$ spawning rate. The number and frequency of flushes depend on spawning rates. A minimum period of 6.33 days between flushes was taken when spawning rate was $2 \%$ and the period was 16.72 days at $10 \%$ spawning rate [17]. However, only one flush was harvested when a spawn rate of $1 \%$ on dry weight basis was used [20].

It is the general experience that the second flush will be the largest. It is not uncommon for the first flush to be the largest and with a few substrates the third flush may occasionally be the largest [23]. The flush number with the highest yield in this experiment was not definite as each substrate had its peak at different periods. On the average, the fifth harvesting period gave the highest fresh mushroom weight and the least was during the second harvesting period which flouts the general experience reported in [23]. The results showed that the tested maize by-products for the cultivation of oyster mushroom influenced the weight of mushroom produced as reported by Mendez et al. [11]. When oyster mushrooms are grown in the field, harvested fruiting bodies yield only $9 \mathrm{~g} / \mathrm{kg}$ substrate [13] compared to the $\sim 42 \mathrm{~g} / \mathrm{kg}$ recorded for sawdust in this experiment. Sawdust has been reported as the best substrate for mycelia growth and fructification [24]. The high harvested mushroom weight from the sawdust treatment could be due to good aeration as has been reported by Chang and Miles [25] that mushroom production was influenced by the composition of the substrate and the degree of aeration. The suitability of the substrates was also confirmed by their comparable biological efficiencies to the traditional sawdust. The nutritional components of mushroom substrates are known to influence mycelia growth [26]. Oyster mushrooms have the ability to utilize biomolecules for their growth [27]. A highly nutritive substrate also improves the sustenance of mycelia vegetative growth which leads to vigorous growth and late pinning [28].

The lipid contents of these residues were not tested in the current experiment; however, according to Naraian et al. [29] maize stalks have higher lipid components than cobs and husks. The lipids present in the maize stalks might have contributed to the high biological efficiency $44.4 \%$ (60.1\% for sawdust) which represents the usable and available nutrients in a growing media. However, in other reports, the biological efficiency reached about $90-97 \%$ after $50-60$ days with a spawn rate of $10 \%$ [30] as compared to the $5 \%$ used here. Although $25 \%$ spawn rate appeared superior, Fan et al. [30] recommended 10\% spawn rate in view of the process economics while Bhatti et al. [17] also recommended 7\% spawning rate on dry weight basis as this resulted in early and high yielding crop of oyster mushroom, with minimum period for maturation of fruiting bodies, maximum number of flushes and fruiting bodies. Supplementation of substrates has become one of the major techniques in mushroom cultivation. An ideal substrate should contain nitrogen (supplement) and carbohydrates for rapid mushroom growth [19]. Rice bran proved to be a suitable material for supplementing the maize residues as substrates. It increased the biological efficiency of all the substrates except for maize cobs. Ayodele and Akpaja [31] reported that supplementation of sawdust with oil palm fibres can enhance mycelia growth and sporophore yield of wood ear mushroom.

\section{Conclusion}

The study demonstrated that maize stalk is potentially suitable for use in commercial oyster mushroom production. Many locally available organic substrates have high potential for utilization as substrates and/or supplement for oyster mushroom production. In this study, even though sawdust is known to be the most suitable substrate for mushroom production, maize residues (with or without rice bran supplement) have also proven to be suitable substrates for oyster mushroom cultivation at the farm level. Maize husk and stalk were the most suitable in terms of the number of fruiting bodies and fresh weight of mushroom and are therefore recommended as potential substrate for cultivation of oyster mushroom. The differences in the results reported by other research workers should be expected since it may be due to the variation in growing requirements for cultivation of oyster mushroom such as temperature, humidity, and light regimens. 


\section{Conflict of Interests}

The authors declare that there is no conflict of interests regarding the publication of this paper.

\section{Acknowledgments}

The authors are grateful to the management and staff of BenCom Youth Association/Enterprise in the Techiman Municipality of the Brong Ahafo Region of Ghana, where this study was conducted.

\section{References}

[1] M. A. Belewu and K. Y. Belewu, "Cultivation of mushroom (Volvariella volvacea) on banana leaves," African Journal of Biotechnology, vol. 4, no. 12, pp. 1401-1403, 2005.

[2] T. H. Quimio, "Why grow mushroom," in Mushroom Growers' Handbook, pp. 1-12, Mushroom World, 1st edition, 2004.

[3] D. J. Royse, Cultivation of Oyster Mushrooms, College of Agricultural Sciences, Pennsylvania State University, State College, $\mathrm{Pa}, \mathrm{USA}, 2003$.

[4] G. C. Wakchaure, "Production and marketing of mushrooms: global and national scenario," in Mushrooms-Cultivation, Marketing and Consumption, M. Singh, B. Vijay, S. Kamal, and C. G. Wakchaure, Eds., Directorate of Mushroom Research, pp. 1522, Solan, India, 2011.

[5] B. O. Onyango, V. A. Palapal, P. F. Arama, S. O. Wagai, and B. M. Gichimu, "Morphological characterization of Kenyan native wood ear mushroom (Auricularia auricula (L. ex Hook.) Underw and the effect of supplemented millet and sorghum grains in spawn production," Agriculture and Biology Journal of North America, vol. 3, pp. 2151-2157, 2010.

[6] S. W. Kang, "What is oyster mushroom," in Mushroom Growers' Handbook, pp. 48-51, Mushroom World, 1st edition, 2004.

[7] N. V. Chiejina and J. O. Olufokunbi, "Effects of different substrates on the yield and protein content of Pleurotus tuberregium," African Journal of Biotechnology, vol. 9, no. 11, pp. 15731577, 2010.

[8] J. C. Rajapakse, P. Rubasingha, and N. N. Dissanayake, “The potential of using cost-effective compost mixtures for oyster mushroom (Pleurotus spp.) cultivation in Sri Lanka," Tropical Agriculture Research Extension, vol. 10, pp. 29-32, 2007.

[9] G. Jonathan, A. Ajayi, I. Oku, and D. Wankasi, "Nutritive value of common wild edible mushrooms from Southern Nigeria," Global Journal of Biotechnology \& Biochemistry, vol. 1, no. 1, pp. 16-21, 2006.

[10] J. Ashraf, M. A. Ali, W. Ahmad, C. M. Ayyub, and J. Shafi, "Effect of different substrate supplements on oyster mushroom (Pleurotus spp.)," Production Food Science and Technology, vol. 1, no. 3, pp. 44-51, 2013.

[11] L. A. Mendez, C. A. S. Castro, R. B. Casso, and C. M. C. Leal, "Effect of substrate and harvest on the amino acid profile of Oyster mushroom (Pleurotus ostreatus)," Journal of Food Composition and Analysis, vol. 18, no. 5, pp. 447-450, 2005.

[12] S. Hassan, A. Y. Mohammad, and K. Kiramat, "Cultivation of the oyster mushroom (Pleurotus ostreatus (Jacq.) P. Kumm) in two different agroecological zones of Pakistan," African Journal of Biotechnology, vol. 10, pp. 183-188, 2011.
[13] N. Badshah, N. Ur-Rehman, and M. Wahid, "Yield and quality of mushrooms grown on different substrates," Sarhad Journal of Agricultural, vol. 8, no. 6, pp. 631-635, 1992.

[14] T. Marimuthu, "Prospects of oyster mushroom cultivation in Tamil Nadu," Journal of Ecobiology, vol. 7, no. 1, pp. 27-34, 1995.

[15] M. Atikpo, O. Onokpise, M. Abazinge et al., "Sustainable mushroom production in Africa: a case study in Ghana," African Journal of Biotechnology, vol. 7, no. 3, pp. 249-253, 2008.

[16] M. Obodai, J. Cleland-Okine, and K. A. Vowotor, "Comparative study on the growth and yield of Pleurotus ostreatus mushroom on different lignocellulosic by-products," Journal of Industrial Microbiology and Biotechnology, vol. 30, no. 3, pp. 146-149, 2003.

[17] M. I. Bhatti, M. M. Jiskani, K. H. Wagan, M. A. Pathan, and M. R. Magsi, "Growth, development and yield of oyster mushroom, Pleurotus ostreatus (Jacq. Ex. Fr.) Kummer as affected by different spawn rates," Pakistan Journal of Botany, vol. 39, no. 7, pp. 2685-2692, 2007.

[18] A. Ingale and A. Ramteke, "Studies on cultivation and biological efficiencies of mushrooms grown on different agro residues," Innovative Romanian Food Biotechnology, vol. 6, pp. 25-28, 2010.

[19] K. B. Khare, J. M. Mutuku, O. S. Achwania, and D. O. Otaye, "Production of two oyster mushrooms, Pleurotus sajorcaju and P. florida on supplemented and un-supplemented substrates," International Journal of Agriculture and Applied Sciences, vol. 6, pp. 4-11, 2010.

[20] J. C. Lozano, "Commercial production of oyster mushroom (Pleurotus ostreatus) in coffee pulp," Fitopatologia Colombiana, vol. 14, no. 2, pp. 42-47, 1990.

[21] M. M. Jiskani, A Brief Outline "The Fungi" Cultivation of Mushrooms, Izhar Publisher, Tando Jam, Pakistan, 1999.

[22] I. Bughio, Yield performance of oyster mushroom, Pleurotus ostreatus (Jacq. ex. Fr.) Kummer on combination of different straws [M.S. thesis], Department of Plant Pathology Sindh Agriculture University, Tando Jam, Pakistan, 2001.

[23] R. H. Kurtzman Jr., "A review Mushrooms: sources for modern western medicine," Micologia Aplicada International, vol. 17, no. 2, pp. 21-33, 2005.

[24] M. Kadiri and I. O. Fasidi, "Variations in chemical composition of Chlorophyllum molybditis (Mayerex. Fr.) Massee and Pleurotus tuber-regium (Fries) during fruit body development," Nigerian Journal of Science, vol. 24, pp. 86-89, 1990.

[25] S. T. Chang and P. G. Miles, Edible Mushrooms and Their Cultivation, CRC Press, Boca Raton, Fla, USA, 1989.

[26] B. O. Onyango, V. A. Palapala, P. F. Arama, S. O. Wagai, and B. M. Gichimu, "Suitability of selected supplemented substrates for cultivation of Kenyan native wood ear mushrooms (Auricularia auricula)," American Journal of Food Technology, vol. 6, no. 5, pp. 395-403, 2011.

[27] J. Poppe, "Use of agricultural waste materials in the cultivation of mushrooms," Mushroom Science, vol. 15, pp. 3-23, 2000.

[28] J. W. Kimenju, G. O. M. Odero, E. W. Mutitu, P. M. Wachira, R. D. Narla, and W. M. Muiru, "Suitability of locally available substrates for oyster mushroom (Pleurotus ostreatus) cultivation in Kenya," Asian Journal of Plant Sciences, vol. 8, no. 7, pp. 510514, 2009.

[29] R. Naraian, R. K. Sahu, S. Kumar, S. K. Garg, C. S. Singh, and R. S. Kanaujia, "Influence of different nitrogen rich supplements during cultivation of Pleurotus florida on corn cob substrate," Environmentalist, vol. 29, no. 1, pp. 1-7, 2009. 
[30] L. Fan, A. Pandey, R. Mohan, and C. R. Soccol, "Use of various coffee industry residues for the cultivation of Pleurotus ostreatus in solid state fermentation," Acta Biotechnologica, vol. 20, no. 1, pp. 41-52, 2000.

[31] S. M. Ayodele and E. O. Akpaja, "Yield evaluation of Lentinus squarosulus (Mont) Sing on selected sawdust of economic tree species supplemented with $20 \%$ oil palm fruit fibers," Asian Journal of Plant Sciences, vol. 6, pp. 1098-1102, 2007. 


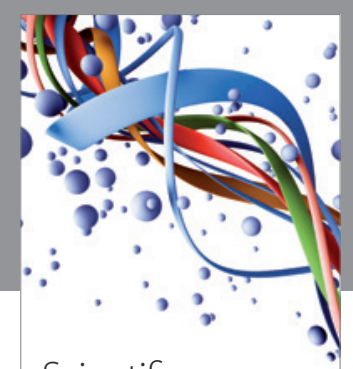

Scientifica
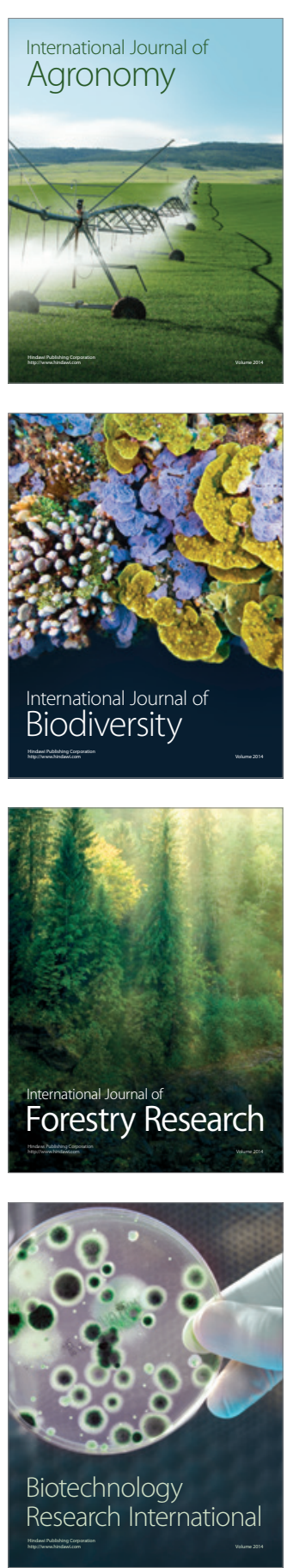
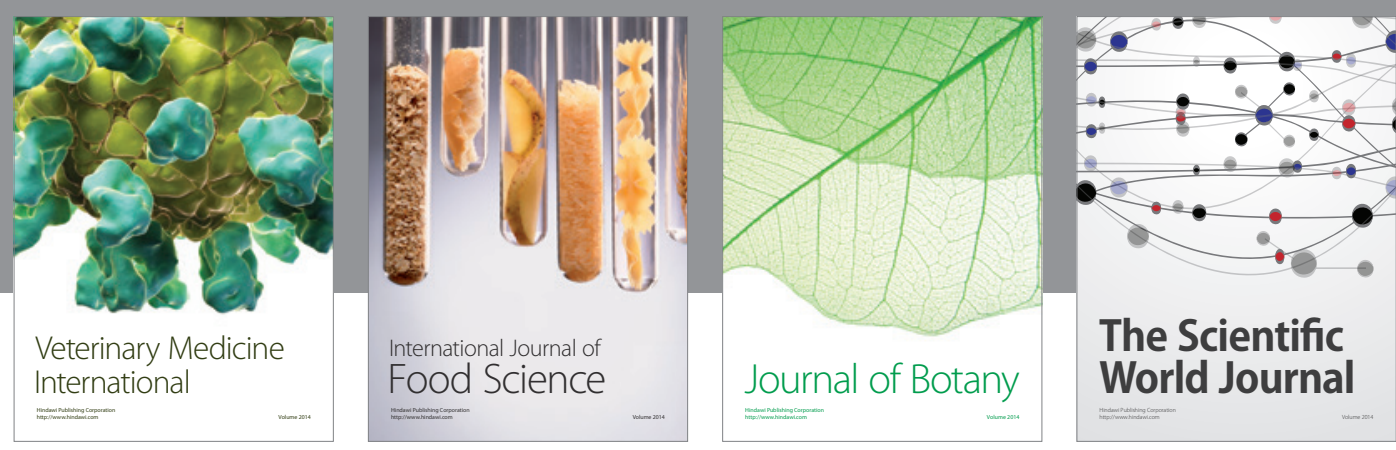

The Scientific World Journal
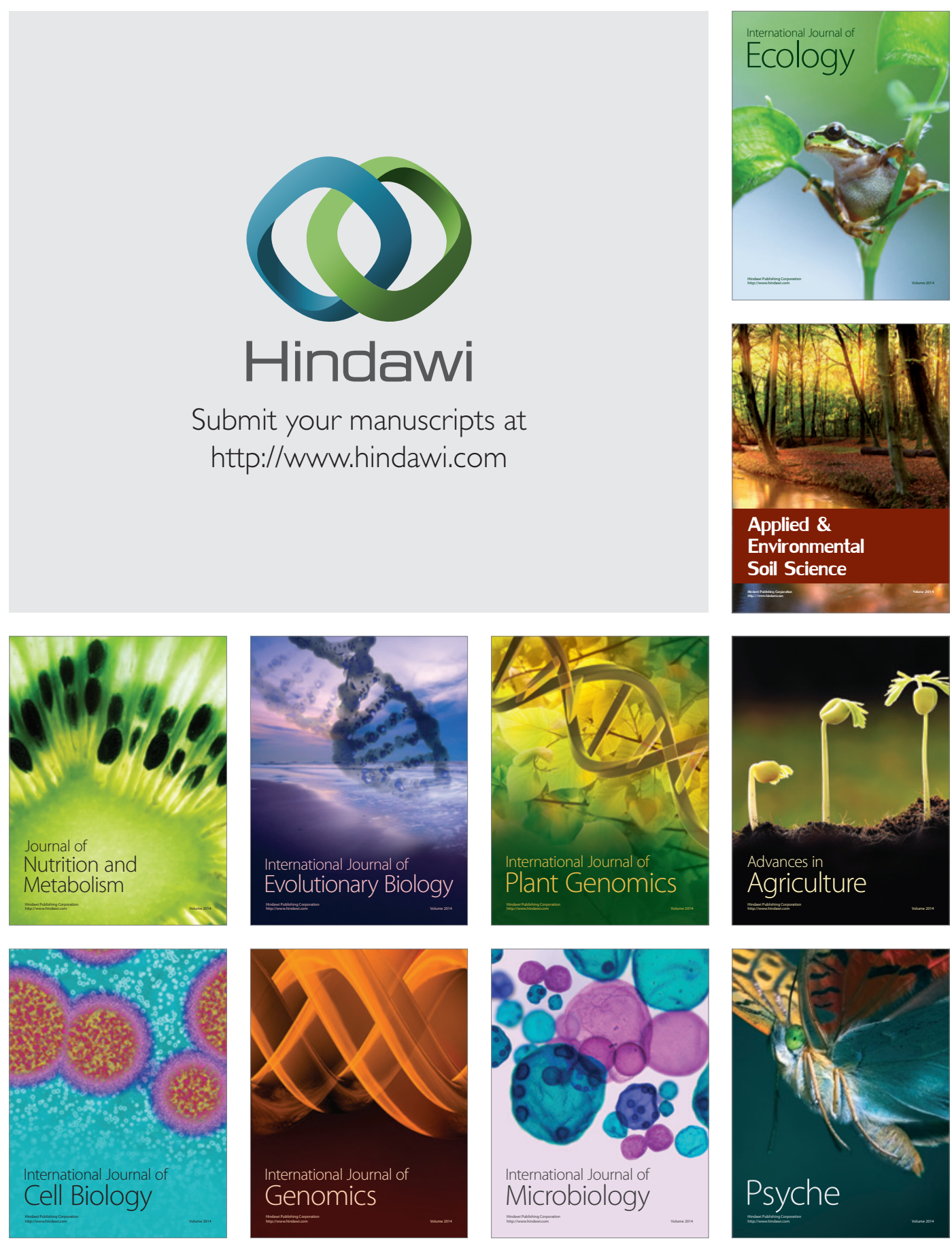